\title{
Formation of Some Cysteine-Containing Peptide Monolayers on Au Electrodes and Their Applications for Metal Ion Sensing and Electrocatalytic Reactions
}

\author{
Guang Shan Xuan and Sunghyun Kim $\div *$ \\ Deparment of Phamacy, Qingdao Lniversity of Science \& Techology, Qingdao 266042, P.R. China \\ ${ }^{\dagger}$ Department of Bioscience and Biotechnologk, Konkuk Lniversitw, Seoul 143-701, Korea. ${ }^{*}$ E-mail: skm looakonkuk.ack kr \\ Received March 25, 2008
}

Key Words : Peptide monolayer. Metal ion sensing. Electrocatalỵsis

The use of biological molecules that already exist in nature offers advantages over using artificially made molecules in developing biosensors or electrocatalysts. Since those molecules have already been best adopted by nature to carry out specific functions. a lot of practical benefit could be acquired by utilizing or mimicking them rather than synthesizing complex molecules. In this regard. amino acids and peptides are favorite syistems in metal ion sensing in a sense that they can act as very effective and often specific ligands for a variety of metal ions. ${ }^{1-6}$ While amme and carboxyl groups of amino acids participate in complexation. an amide nitrogen atom is also mvolved in complexation in the case of peptides. This often forms a chelate and a peptide-metal ion bunding becomes significantly stronger as a result. Detailed accounts have been treated by Sigel and Martin $^{7}$ and other authors. ${ }^{8}$

Despite the fact that ammo acids and peptides readily form complexes with metal ions. electrochemical study of those complexes is scarce. It was not until recently when a first report by Yang et $\alpha l^{9}$ appeared for the electrochemical metal ion detection. They syinthesized a tripeptide system. GlyGly-His, on top of an alkanethiol self-assembled Au electrode to detect copper ions. Since then. many papers regard1ng various electrochemical aspects of a peptide-metal binding have been published. . $^{\text {-1] }}$ Here we present our preliminary results of metal ion sensing and electrocatalytic reactions using cysteme-containing simple peptide monolayers constructed on a Au surface. Cýsteine was chemisorbed on the Au surface wia Au-S bonding and other amino acids were formed by the usual peptide synthesis method. This way two types of peptide monolayers were prepared: With a $\mathrm{Al} /$ GSH-His system (GSH: glutathione. $\gamma$-L-glutamyl-L-cy'steinyl-glycine). copper ions of nano molar concentration were detected by accumulating $\mathrm{Cu}^{2+}$ on the peptide monolayer. With a $\mathrm{Au} / \mathrm{Cy}$ s-Cys-Cys/M(M $=\mathrm{Cu}^{2+}$. Fe- $)$ system. electrocatalytic oxidation of ascorbic acid (AA) and reduction of hỵdrogen peroxide were perfomed.

Figure 1 shows cyclic voltammograms of a Au/GSH-His/ $\mathrm{Cu}$ system after immersing a $\mathrm{Au} / \mathrm{GSH}-\mathrm{His}$ electrode in a $\mathrm{Cu}^{-}$-containing solution and transferrmg into the $\mathrm{Cu}^{2}$-free electrolyte. Fairly stable voltammograms were obtamed. Without copper ion. no faradaic current was observed. Redox peaks at +0.33 and $+0.010 \mathrm{~V}$ are assigned to the $1-\mathrm{e}^{-}$redox reactions of a $\mathrm{Cu}^{+} / \mathrm{Cu}^{-}$couple as indicated in other studies. ${ }^{13.14}$ With only GSH laỵer on $\mathrm{Au}$. current slightly decreased upon multi potential cycling. This means copper ions form a more stable complex with histidine in which imidazole moiety of histidine is involved in complexation. Full copper ion accumulation was complete after $c a .10 \mathrm{~min}$. Treating the $\mathrm{Au} / \mathrm{GSH}-\mathrm{His} / \mathrm{Cu}$ electrode with EDTA solution. copper 1ons were completely removed from the modified

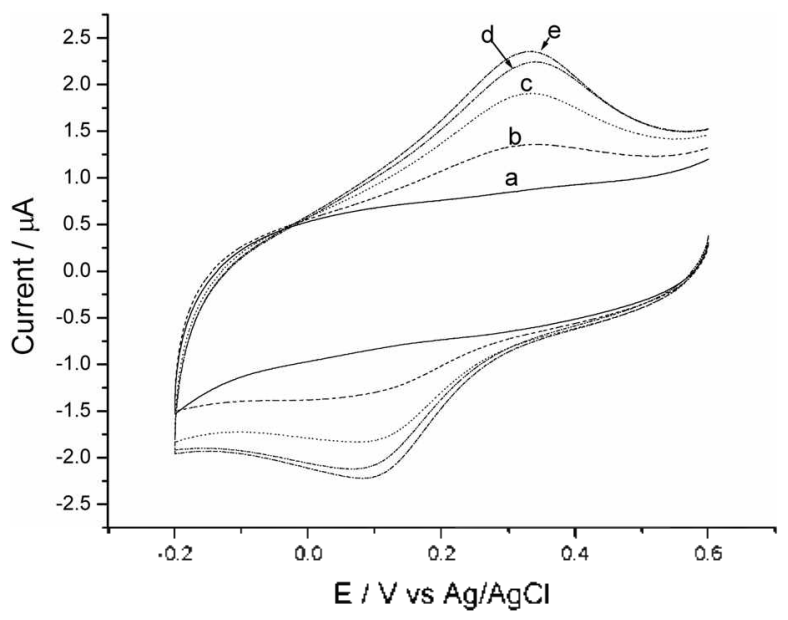

Figure 1. CVs of a Alv/GSH-His/Cu system as a function of immersion time: 0 (a), 1 (b), 4 (c), 8 (d), and $10 \mathrm{~min}$ (e). The electrolyte was $\mathrm{pH} 7.0$ acetate buffer. $\left[\mathrm{Cu}^{2+}\right]=0.1 \mathrm{mM}$. Scan rate $=100 \mathrm{mV} \mathrm{s}^{-1}$.

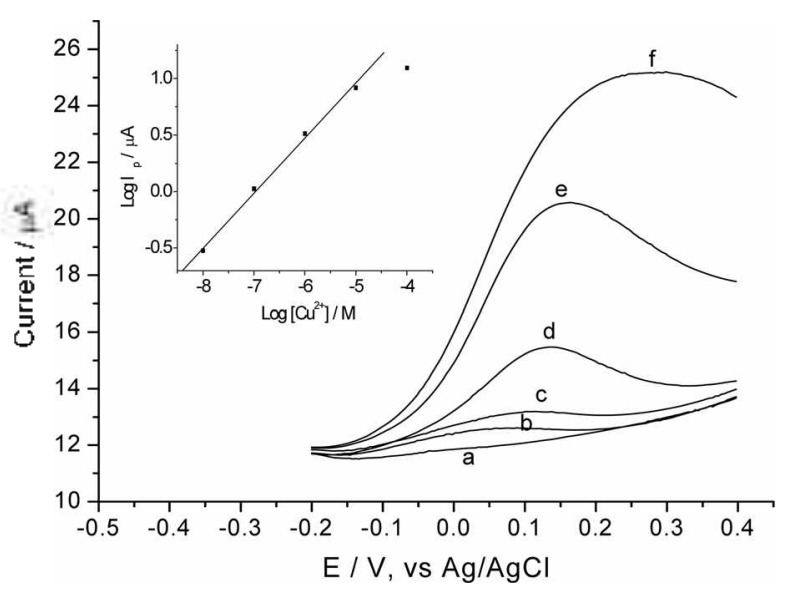

Figure 2. Copper ion accumulation tested with Osteryoung square wave voltammetry for $\mathrm{Cu}^{2-}$ concentrations of $10^{-9}$ (a), $10^{-8}$ (b), $10^{-7}$ (c) $10^{-i}$ (d) $10^{-5}$ (e), and $10^{-1} \mathrm{M}$ ( $\mathrm{f}$ ). OSWV was done by applying square wave of $4 \mathrm{mV}$ step height and $60 \mathrm{mV}$ pulse height with 60 $\mathrm{Hz}$ trequency. Inset: Plot of $\mathrm{Log} \mathrm{i}_{\mathrm{p}}$ ws $\mathrm{Log}\left[\mathrm{Cu}^{2+}\right]$. Sampling time = $8.3 \mathrm{~ms}$. 

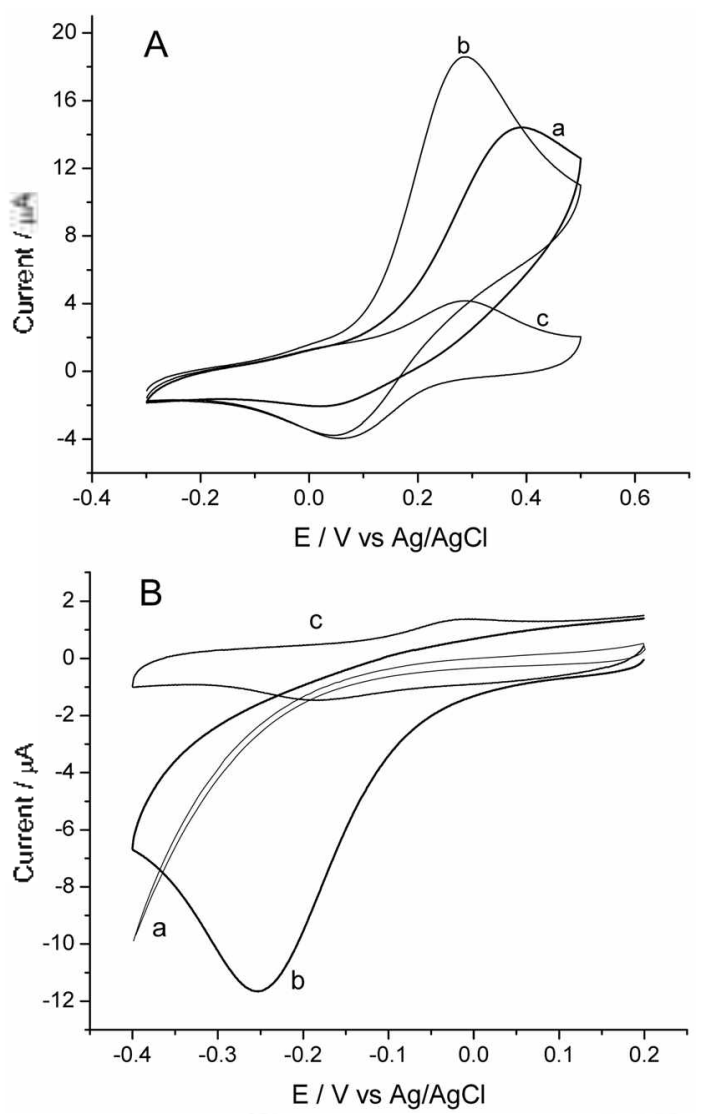

Figure 3. (Panel A) Cyclic voltanmograms of AA oxidation on a bare Au (curve a) and on a Au/Cvs-Cvs-Cys/Cu electrode (curve b). Curve $\mathrm{c}$ represents a voltammogram of a $\mathrm{Au} / \mathrm{Crs}-\mathrm{Crs}-\mathrm{Crs} / \mathrm{Cu}$ electrode. The electroly te was buffered at $\mathrm{pH} 7.0$. $[\mathrm{AA}]=0.91 \mathrm{mM}$. Scan rate $=50 \mathrm{mV} \mathrm{s}^{-1}$. (Panel B) Cyclic voltanmograms of $\mathrm{H}_{2} \mathrm{O}_{2}$ reduction on a bare $\mathrm{Au}$ (curve a) and on a Au/Cys-Cys-Cys/ $\mathrm{He}$ electrode (curve b). Curve $\mathrm{c}$ represents a voltammogram of a Au/ $\mathrm{Cys}-\mathrm{Cys}-\mathrm{Cys} / \mathrm{Le}$ electrode. $\left[\mathrm{H}_{2} \mathrm{O}_{2}\right]=3 \mathrm{~mm}$.

surface since the formation constant of $\mathrm{Cu}^{i^{-}-}$-EDTA is much larger than that of $\mathrm{Cu}^{\hat{u}^{-}}$-peptide. Almost identical voltammetric features were obtained when the electrode was immersed back in a $\mathrm{Cu}^{2+}$-containing solution. indicating that the peptide layer remained intact (data not shown). Even very low concentrations of copper ions can be determined by accumulating them onto the electrode. Figure 2 shows Osteryoung square wave voltammetry of various $\mathrm{Cu}^{2+}$ concentrations. Copper ions down to $10^{-8} \mathrm{M}(0.64 \mathrm{ppb})$ could be detected with at least 3 orders of magnitude linearity. Deviation at higher concentrations indicates that the copper binding sites of peptides are saturated with $\mathrm{Cu}^{2+}$ ions.

Figure 3 shows $\mathrm{Au} / \mathrm{Cys}-\mathrm{Cys}-\mathrm{Cys} / \mathrm{M}\left(\mathrm{M}=\mathrm{Cu}^{2-} \cdot \mathrm{Fe}^{2++}\right)$ electrodes can be used as an electrocatalyst for the oxidation of ascorbic acid ${ }^{15}$ (Panel A) and reduction of hydrogen peroxide $^{16}$ (Panel B). Metal ion complexation was done by immersing the $\mathrm{Au} / \mathrm{Cys}-\mathrm{Cys} / \mathrm{Cys}$ electrodes into the $\mathrm{Cu}^{3-}$ and $\mathrm{Fe}^{3+}$-containing solutions. A Au/Cys-Cys-Cys/ $\mathrm{Cu}^{2+}$ electrode was used for AA oxidation. On a bare Au electrode AA is irreversibly oxidized at $+0.39 \mathrm{~V}$ (curve a. Fig. 3A). The modified electrode showed a redox couple corresponding to $\mathrm{a} \mathrm{Cu}^{3+} / \mathrm{Cu}^{+}$redox reactions at +0.06 and $+0.28 \mathrm{~V}$ (curve c). Upon addition of AA. AA undergoes electrocatalytic oxidation catalyzed by $\mathrm{Cu}^{2-}$ species formed by the oxidation of $\mathrm{Cu}^{+}$according to the following reaction (curve b).

$$
\begin{aligned}
& \mathrm{Au} / \mathrm{Cys}-\mathrm{Cys}-\mathrm{Cys} / \mathrm{Cu}^{+} \rightarrow \mathrm{Au} / \mathrm{Cys}-\mathrm{Cys}-\mathrm{Cys} / \mathrm{Cu}^{2-}+\mathrm{e}^{-} \\
& 2 \mathrm{Au} / \mathrm{Cys}-\mathrm{Cys}-\mathrm{Cys} / \mathrm{Cu}^{++}+\mathrm{HA}^{-} \rightarrow \\
& 2 \mathrm{Au} / \mathrm{Cys}-\mathrm{Cys}-\mathrm{Cys} / \mathrm{Cu}^{-}+\mathrm{D}+\mathrm{H}^{+}
\end{aligned}
$$

where $\mathrm{HA}^{-}$and $\mathrm{D}$ represent $\mathrm{AA}$ and an oxidized form of AA. respectively. Catalytic current begins to appear as $\mathrm{Cu}^{-}$ is oxidized to $\mathrm{Cu}^{2+}$. Peak potential was shifted by $100 \mathrm{mV}$ from 0.39 to $0.29 \mathrm{~V}$, indicating $\mathrm{Au} / \mathrm{Cys}-\mathrm{Cys}-\mathrm{Cys} / \mathrm{Cu}$ is a good electrocatalytic system.

Panel B shows the reduction of hydrogen peroxide by $\mathrm{Au} /$ Cys-Cys-Cys/ $/ \mathrm{Fe}^{2+}$. This electrode displays redox peaks at -0.25 and $-0.0 \mathrm{~V}$ corresponding to the $\mathrm{Fe}^{2-} / \mathrm{Fe}^{\hat{2-}}$ couple in the absence of $\mathrm{H}_{2} \mathrm{O}_{2}$ (curve c). In $3 \mathrm{mM} \mathrm{H}_{2} \mathrm{O}_{2}$ solution. a large reduction peak appeared at $-0.25 \mathrm{~V}$ (curve b) according to the following reaction. Catalytic current begins to appear as $\mathrm{Fe}^{3-}$ species is reduced to $\mathrm{Fe}^{3+}$. However. no appreciable current flows on a bare Au electrode (curve a).

$$
\begin{gathered}
\mathrm{Au} / \mathrm{Cys} \text {-Cys-Cys } / \mathrm{Fe}^{3+}+\mathrm{e}^{-} \rightarrow \mathrm{Au} / \mathrm{Cys}-\mathrm{Cys}-\mathrm{Cys} / \mathrm{Fe}^{2-} \\
2 \mathrm{Au} / \mathrm{Cys}-\mathrm{Cys}-\mathrm{Cys} / \mathrm{Fe}^{2-}+\mathrm{H}_{2} \mathrm{O}_{2}+2 \mathrm{H}^{-} \rightarrow \\
2 \mathrm{Au} / \mathrm{Cys}-\mathrm{Cys}-\mathrm{Cys} / \mathrm{Fe}^{3+}+\mathrm{H}_{2} \mathrm{O}
\end{gathered}
$$

In this communication. we have shown several examples to convince that peptide-modified electrodes are very useful in metal ion sensing and in electrocatalytic reactions. Taking full advantages of diverse peptide chemistry. peptide-modified electrode systems will find more useful applications in real world.

Acknowledgments. This work was supported by the Konkuk University.

\section{References}

1. Gooding, J. J:- Hibbert, D. B.; Yang. W. Sensors 2001. 1,75.

2. Yamamura. T.: Watanabe. T.: Kikuchi. A.: Yamane. T.: Ushiyama. M.: Hirota. H. Inorg. Chent 1997. 36.4849.

3. Harlyk. C.: Nieto. O.: Bordit1. G.: Rodriguez. A. R. J. Electromal. Chem $1998,+51,267$.

4. Scheibler, L.: Dumy. P.: Boncheva, M.; Leufgen, K.: Mathieu. H.J:- Mutter, M.: Vogel. H. Angew. Chem. Iht Ed 1999, $38,696$.

5. Strong. A. E.: Moore. B. D. Chent Conmum 1998. 473.

6. Torado. A.: Walkup. G. K.: Imperiali. B. J. An. Chen. Soc. 1998. 120.609 .

7. Sigel, H.: Martin. R. B. Chem. Rev 1982,82. 385.

8. Kozlowski. H.: Bal, W. Dyba, M: Kowalik-Jankowskia, T. Coord Chem Rev 1999. 184.319

9. Yang. W.: Jaramillo. D.: Gooding. T. T.: Hibbert. D. B.: Zhang. R.: Willett. G. D.: Hisher. K. T. Chent. Conmm 2001. 1982.

10. Yang. W.: Gooding. .T. T.: Hibbert. D. B. Analysf 2001. 126. 1573.

11. Chow. E.: Gooding. J. J. Electroanalysis 2006. 18. 1437.

12. Chow. E. Hibbert. D. B.: Gooding. J. J. Anal Chim Ata 2005. 543. 167 .

13. Domenech. A.: Garcia-Espana. E.: Luis. S.: Marcelino. V.: Miravet. I. F. Lhorg. Chim. Acta 2000. 299. 238.

14. Krishnapriya. K. R.: Aruthimar. S. P: Kandaswamy. M. Spectrochim Acta Part A 2008, 69. 1077.

15. Stolarezyk. K.: Bilewicz. R.: Siegfried, L; Kaden, T. Inorg. Chim Acta 2003. 348. 129.

16. Paczestiak. T.: Sobkowiak. A. J. औhol Catal A. Chent 2003. 194. 1 . 